\title{
SAMFUNDSSANKTIONER OG SAMFUNDSTILTAG I DANMARK
}

\section{AF FORSKNINGSCHEF, DR. JUR. BRITTA KYVSGAARD}

In the early 1970 's, Denmark abolished a number of special sanctions designed for the treatment and rehabilitation of offenders within institutions. Within a few years, however, the Danish criminal justice system began to focus on community sanctions as an alternative to imprisonment. The first community sanction experimented with was community service, which was introduced on a trial basis in 1982 and made statutory ten years later. Community service remains a viable alternative to incarceration in Denmark, and its scope of application has gradually broadened over time. During the 1990's, a number of other community sanctions and measures were introduced including a special contract for juveniles on probation, and various treatment programs for sex offenders, drug-addicted offenders, and drunken drivers with alcohol dependencies. A victim-offender mediation programme was also initiated, though not as an alternative to imprisonment, but as a supplement. This article outlines the scope and application of the community sanctions available in Denmark today. It is concluded that apart from the area of traffic violations, these sanctions and measures have not yet come to play a dominant practical role in the penal system, though they do serve important symbolic and political purposes. Community sanctions and measures are, however, likely to develop further and to become of more significant importance in the future. *

\section{Historisk overblik}

Samfundssanktioner eller alternativer til frihedsstraf er et fænomen, der er næsten 100 år gammelt. I 1905 introduceredes den betingede dom. Da havde prøveløsladelse allerede eksisteret i mere end 30 år, idet den indførtes med straffeloven af 1873, dog alene som en undtagelse. Ikke så mange år efter blev det muligt at give tiltalefrafald. Det skete i 1919 med gennemførelse af retsplejeloven. Vilkår i forbindelse med tiltalefrafald blev imidlertid først muligt $\mathrm{i}$ 1933.

Så fulgte en periode, hvor der skete meget lidt på dette område. Næste årstal, der kan føjes til, er 1973. Perioden 1933-1973 svarer, interessant nok, præcis til den, der ofte refereres til som behandlingsæraen, idet den række af særforanstaltninger, der blev gennemført med straffeloven af 1930, trådte i kraft i 1933

\footnotetext{
- Title in English: Community Sanctions and Measures in Denmark. Original in Danish.
} 
og ophævedes igen i 1973. Hvorvidt der er en sammenhæng mellem fokuseringen på særforanstaltninger og stilstanden på samfundssanktionsfronten, er uvist, men nok ikke usandsynlig. Med indførelse af de mange forskellige former for helt og delvis tidsubestemte sanktioner i 1933 øgedes differentieringsmulighederne i sanktionssystemet således betydeligt, og det kan have lagt en dæmper på behovet for at indføre nye sanktioner.

Efter ophævelsen af særforanstaltningerne i 1973 indtrådte en ny situation. I de andre nordiske lande, herunder især i Sverige og i Finland, var der et mere formelt straffeideologisk skifte - fra behandlingsideologien til en nyklassiske strafferet.' Almenpræventionen blev rehabiliteret, og proportionalitetsprincippet blev igen det førende princip ved strafudmålingen.

Tilsvarende klare ideologiske skift forekom ikke i Danmark. Der kan derimod tales om, at Danmark skiftede fokus fra de traditionelle sanktioner til de alternative former. Eller, kan det hævdes, at der efter ophævelsen af særforanstaltningerne i 1973 opstod et behov for at tilføre sanktionssystemet nye muligheder, og at de alternative former da naturligt kom i centrum.

Allerede i 1973 indførtes mulighed for alternativ afsoning i henhold til strfl. § 49, stk. 2.

Et par år efter begyndte man at overveje nye sanktionsformer, egentlige alternativer til frihedsstraf, idet der i 1975 blev der nedsat en arbejdsgruppe vedrørende alternativer til frihedsstraf. Af kommissoriet fremgår bl.a., at arbejdsgruppen "har til opgave at pege på foranstaltninger, der vil være egnede til at videreføre den udvikling mod øget anvendelse af ikke-frihedsberøvende sanktioner". ${ }^{2}$ Endvidere siges, at arbejdsgruppen "bør bl.a. så vidt muligt vurdere, hvilke ændringer i reaktionsmønstret, der ville være nødvendige for at tilvejebringe en nedbringelse af det fremtidige belæg af frihedsberøvede til eksempelvis $2.000,2.500 \mathrm{og} 3.000$ personer". ${ }^{3} \mathrm{I} 1975$ var det gennemsnitlige fangetal på knap 3.400 personer.

I den betænkning, denne arbejdsgruppe afgav to år senere, begrundes ønsket om at mindske fangebefolkningen med følgende forhold:

1) Humanitetshensyn. Frihedsberøvelsen indebærer "en betydeligt belastning for den, der udsættes herfor, og vil ofte have en række negative virkninger, der strækker sig ud over frihedsberøvelsens ophør". ${ }^{4}$

2) Hensynet til den specialpræventive virkning. Der henvises til forskning, der har påvist, at frihedsstraffen medfører en negativ personlighedsudvikling, og at straffen har en ringere specialpræventiv virkning end andre sanktioner.

3) Proportionalitetshensyn. Det er først og fremmest mange ejendomsforbrydere blandt de frihedsberøvede, men betydningen af disse forbrydelser må, som følge af en almen velstandsstigning og øget udbredelse af private forsikringen, antages at være mindsket.

4) Økonomiske hensyn. Endelig anføres, at fængselsstraffen er betydeligt mere omkostningskrævende end andre sanktioner. 
I betænkningen peges især på to nye sanktionsformer, som det efter arbejdsgruppens vurdering er væsentligt at overveje: Samfundstjeneste og natfængsel. Weekendfængsel har også været drøftet, men man finder ikke denne sanktionsform anbefalelsesværdig. Endvidere har arbejdsgruppen vurderet sanktionsformer, svarende til henholdsvis den finske ordning med straffövervakning og de daværende svenske drøftelser om en ordning med intensivövervakning. Arbejdsgruppen har dog en række betænkeligheder i forhold til sådanne ordninger, herunder ikke mindst, at vanskelighederne med at få den dømte til at overholde forpligtelserne forventes at blive store, også fordi sanktionen mangler meningsfuldt indhold. Endelig nævner arbejdsgruppen kort en række andre udenlandske alternative sanktionsformer, men ingen af disse anbefales.

Af nye sanktionsformer er det alene arbejdsgruppens forslag om samfundstjeneste, der senere er gennemført. Ordningen startede i 1982 på forsøgsbasis og blev i 1992 lovfæstet.

Et andet af arbejdsgruppen forslag til begrænsning af fangepopulationen er dog også gennemført, nemlig en nedsættelse af mindstetiden for prøveløsladelse. I 1982 blev mindstetiden nedsat fra 4 til 3 mdr.

Mens der kom til at gå en rum tid, fra ideen om samfundstjeneste blev fostret, til den blev lovfæstet, er det til gengæld det seneste tiår gået stærkt med at indføre nye samfundssanktioner $\mathrm{og}$ andre tiltag $\mathrm{i}$ frihed:

- I 1990 gennemførtes muligheden for, at spritbilister, der har behov for behandling for alkoholmisbrug, kunne modtage behandling som alternativ til en hæftestraf.

- Samme år blev der gennemført en toårig forsøgsordning med ungdomskontrakt. Ordningen, der vedrører unge, der modtager et tiltalefrafald, blev i 1998 gjort permanent.

- I 1995 indførtes - på forsøgsbasis - en mulighed for at stofmisbrugere kunne idømmes betinget dom med vilkår om behandling som alternativ til en ubetinget frihedsstraf.

- I 1997 indførtes en tilsvarende forsøgsordning for seksualforbrydere.

- Samme år blev muligheden for at anvende samfundstjeneste i kombination med en bøde eller en ubetinget dom udvidet.

- I 1998 startede et forsøg med konfliktråd.

- I 2000 udvidedes området for brug af samfundstjeneste primært med henblik på spiritus- og promillekørsel. Samtidig gennemførtes et forslag om betingede domme med vilkår om alkoholistbehandling for spirituskørsel som alternativ til en hæftestraf.

- Seneste skud på stammen er et forslag om en ny ungdomssanktion, der blev fremsat foråret 2001.

Det er disse sanktioner og ordninger, der skal omtales i det følgende. 


\section{Alternativer til frihedsstraf}

Under denne overskift behandles de sanktioner, der idømmes ved domstolene, og som helt eller delvis afløser en frihedsstraf.

\section{a) Samfundstjeneste}

Samfundstjeneste har længe repræsenteret nyheden på det sanktionspolitiske felt. Mens de traditionelle strafformer enten vedrører fratagelse af penge eller af frihed, kan samfundstjeneste ses som en sanktion, der fratager lovovertræderen fritid, idet den ulønnede samfundstjeneste skal udføres uden for lovovertræderens arbejdstid. I og med at fritiden i stigende grad er blevet et værdsat knaphedsgode, kan det umiddelbart synes oplagt, at nye straffetiltag retter sig mod denne livssektor. Mulighederne på dette område begrænses dog i høj grad af, at fritiden langt fra altid er et knaphedsgode, men ofte findes $i$ alt for rigt mål for de mange lovovertrædere uden arbejde, familie og socialt netværk.

Forsøget med samfundstjeneste startede som et geografisk begrænset forsøg i 1982 og blev i 1985 udvidet til hele landet. Som nævnt blev sanktionen lovfæstet i 1992, dog ikke som en egentlig selvstændig sanktion, men som et særligt vilkår til betinget dom, jf. straffelovens $\S 62$, stk. 1: "Såfremt betinget dom efter reglerne i $\S \S 56$ og 57 ikke findes tilstrækkelig, kan retten, hvis tiltalte findes egnet hertil, afsige betinget dom med vilkår om samfundstjeneste."

I forbindelse med udformningen af samfundstjenestesanktionen blev det ivrigt diskuteret, i hvilket omfang man kan og skal sikre sig, at den rent faktisk anvendes som alternativ til frihedsstraf. Mens samfundstjeneste fungerede som forsøgsordning, var den udtrykkeligt begrænset til tilfælde, hvor ubetinget frihedsstraf er forskyldt. Da Straffelovrådet behandlede forslaget om samfundstjeneste ønskede et mindretal, at denne ordning skulle fortsætte, mens et flertal gik ind for ovennævnte formulering i straffeloven. ${ }^{5}$ Dermed er der åbnet for, at samfundstjeneste kan dække grænseområdet mellem betinget og ubetinget straf, og ikke alene være et klart alternativ til ubetingede straffe. En analyse af en række domme synes at bekræfte dette indtryk, idet analysen viser, at samfundstjeneste - $\mathrm{i}$ et kontinuum fra betinget dom til ubetinget dom - falder mellem disse to sanktionsmuligheder, og at samfundstjeneste antagelig ligger lidt nærmere området for de betingede domme end området for de ubetingede domme. ${ }^{6}$

Brugen af samfundstjeneste er øget i løbet af især de seneste år. Det er ikke mindst sket som følge af pres fra Kriminalforsorgens side og et politisk pres. Med henblik på at øge muligheden for at anvende samfundstjeneste blev § 64

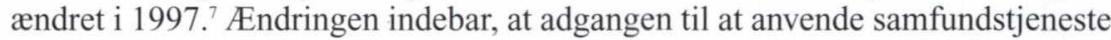
i kombination med en bøde eller en ubetinget dom efter $\S 58$, stk. 1, blev udvidet. Og med henblik på at sikre, at samfundstjeneste bliver overvejet i alle potentielle sager med berigelseskriminalitet, indførtes i 2000 en regel om, at der skal indhentes en egnethedsvurdering for alle berigelseskriminelle (ud over røveri), der er førstegangsstraffede - også selv om anklagemyndigheden i det konkrete tilfælde vil påstå ubetinget frihedsstraf. 
Figur 1. Antal domme med vilkår om samfundstjeneste, 1985-2000, dog eksklusiv fardselssager $i 2000$.

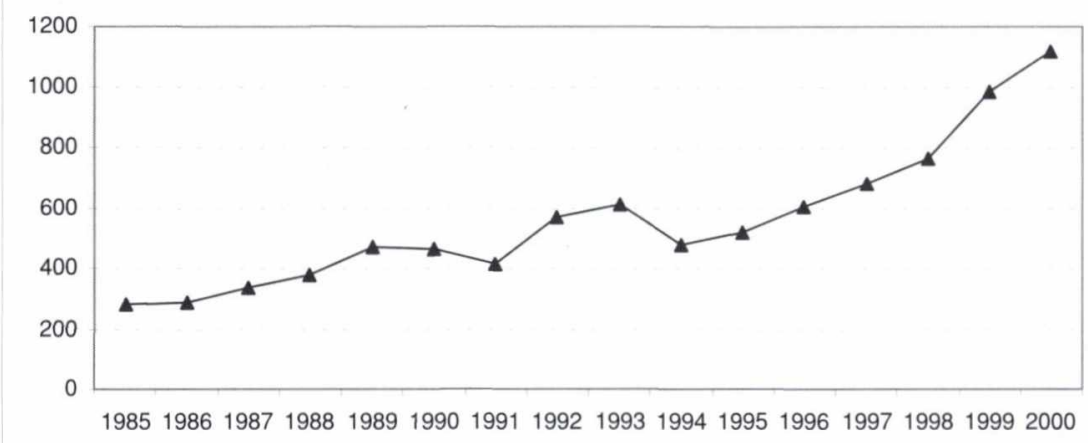

Samfundstjeneste ser ud til at være en meget folkeyndet sanktionsform. En undersøgelse af borgeres syn på straffene viser således, at almindelige borgere meget hyppigere end dommere mener, at en sag bør føre til samfundstjeneste. ${ }^{8}$

En væsentlig grund til, at sanktionen er så populær, er antagelig, at der stort set kun er hørt rosende ord om ordningen. Skandalesager er ikke forekommet. Desuden viser de recidivundersøgelser, Kriminalforsorgen foretager, at recidiv efter samfundstjeneste er meget lavt. I den seneste undersøgelse ses en recidivprocent på kun $17 \%$ for samfundstjenestedømte, mens recidiv efter strafafsoning ligger på omkring $50 \% .{ }^{9}$ Selv om dette ikke fortæller noget om sanktionens kriminalpræventive effekt, bliver det ganske ofte tolket ud fra den synsvinkel. Nogen egentlig evaluering af effekten af samfundstjeneste er der ikke foretaget.

Hovedområdet for anvendelse af samfundstjeneste er berigelseskriminalitet (ekskl. røveri) samt dokumentfalsk og brugstyveri. ${ }^{10}$

I 2000 blev der fra politisk hold rejst kritik af, at samfundstjeneste i stigende grad anvendes i voldssager, jf. også tabel 1. Dette skal antagelig ses i forlængelse af en generel strafskærpelse på voldsområdet i 1990'erne samt i sammenhæng med, at mange af de tiltalte i mindre alvorlige voldssager er tidligere ustraffede og også i øvrigt yderst velegnede til at afsone en straf som samfundstjeneste. 
Tabel 1. Domme til samfundstjeneste 1990-1999 fordelt efter kriminalitetens art.

\begin{tabular}{|l|l|l|l|l|l|l|l|l|l|l|l|}
\hline & $\mathbf{1 9 9 0}$ & $\mathbf{1 9 9 1}$ & $\mathbf{1 9 9 2}$ & $\mathbf{1 9 9 3}$ & $\mathbf{1 9 9 4}$ & $\mathbf{1 9 9 5}$ & $\mathbf{1 9 9 6}$ & $\mathbf{1 9 9 7}$ & $\mathbf{1 9 9 8}$ & $\mathbf{1 9 9 9}$ & $\mathbf{2 0 0 0}$ \\
\hline Tyveri & $28 \%$ & $33 \%$ & $42 \%$ & $34 \%$ & $\mathbf{2 8} \%$ & $30 \%$ & $31 \%$ & $31 \%$ & $27 \%$ & $22 \%$ & $20 \%$ \\
\hline Røveri & $8 \%$ & $6 \%$ & $4 \%$ & $\mathbf{7} \%$ & $6 \%$ & $\mathbf{4} \%$ & $7 \%$ & $6 \%$ & $6 \%$ & $6 \%$ & $7 \%$ \\
\hline Anden berigelse & $42 \%$ & $39 \%$ & $42 \%$ & $42 \%$ & $49 \%$ & $47 \%$ & $44 \%$ & $42 \%$ & $41 \%$ & $37 \%$ & $33 \%$ \\
\hline Hærværk & $1 \%$ & $2 \%$ & $0 \%$ & $1 \%$ & $1 \%$ & $2 \%$ & $1 \%$ & $1 \%$ & $1 \%$ & $2 \%$ & $1 \%$ \\
\hline Narkotika & $6 \%$ & $5 \%$ & $4 \%$ & $6 \%$ & $8 \%$ & $6 \%$ & $4 \%$ & $4 \%$ & $7 \%$ & $7 \%$ & $9 \%$ \\
\hline Vold & $10 \%$ & $8 \%$ & $4 \%$ & $5 \%$ & $5 \%$ & $4 \%$ & $6 \%$ & $9 \%$ & $10 \%$ & $19 \%$ & $23 \%$ \\
\hline Sex & $1 \%$ & $0 \%$ & $1 \%$ & $1 \%$ & $1 \%$ & $1 \%$ & $1 \%$ & $1 \%$ & $1 \%$ & $2 \%$ & $0 \%$ \\
\hline Anden personfarlig krim & $2 \%$ & $2 \%$ & $0 \%$ & $1 \%$ & $0 \%$ & $1 \%$ & $1 \%$ & $2 \%$ & $2 \%$ & $1 \%$ & $1 \%$ \\
\hline Straffelov i øvrigt & $3 \%$ & $3 \%$ & $1 \%$ & $2 \%$ & $2 \%$ & $3 \%$ & $3 \%$ & $4 \%$ & $4 \%$ & $3 \%$ & $4 \%$ \\
\hline Særlov i øvrigt & $0 \%$ & $0 \%$ & $2 \%$ & $1 \%$ & $0 \%$ & $2 \%$ & $2 \%$ & $0 \%$ & $1 \%$ & $1 \%$ & $2 \%$ \\
\hline I alt & $100 \%$ & $100 \%$ & $100 \%$ & $100 \%$ & $100 \%$ & $100 \%$ & $100 \%$ & $100 \%$ & $100 \%$ & $100 \%$ & $100 \%$ \\
\hline I alt $(N)$ & 462 & 417 & 571 & 608 & 479 & 516 & 606 & 679 & 767 & 983 & 1113 \\
\hline
\end{tabular}

Indtil nedennævnte lovændring i 2000 blev samfundstjeneste fastsat med mindst 40 timer og maksimalt 240 timer. Der er ikke i Danmark som i en del andre lande en klar omregningsfaktor mellem frihedsstraffens længde og antal timers samfundstjeneste. Frihedsstraffens længde er heller ikke i alle tilfælde udmålt. På baggrund af de domme, hvor frihedsstraffens længde er udmålt, er det dog, som vist i figur 2, muligt at sammenholde straffens længde med det idømte antal timer. 
Figur 2. Forholdet mellem antal timer $i$ samfundstjeneste og den idømte strafs laengde, 1996."

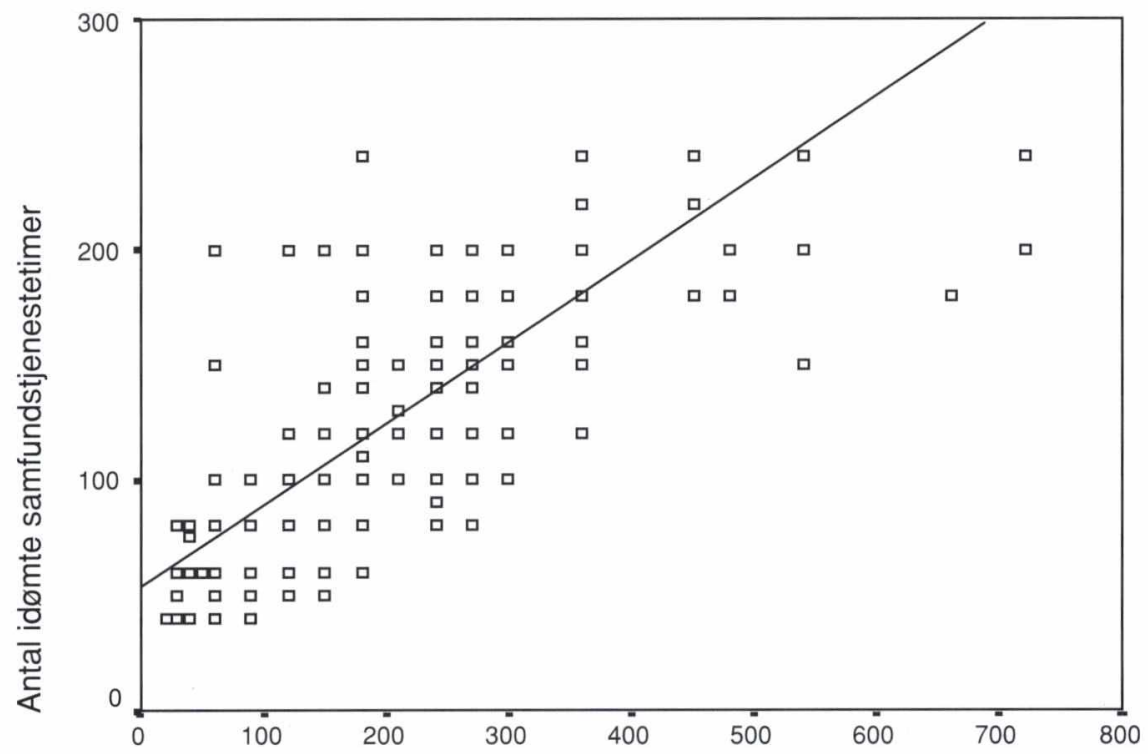

Den betingede doms længde i dage

Figur 2 antyder, at der er en vis spredning i antal timer i samfundstjeneste i forhold til straffens længde, men statistiske analyser viser dog samtidig, at der er en sammenhæng her imellem. Forholdet mellem antal timers samfundstjeneste og straffens længde kan beskrives ved den linie, der er indtegnet i figuren, således:

Antal timer i samfundstjeneste $=53,4+(0,356 \times$ straflængden $i$ antal dage $)$.

Dvs. at det idømte antal samfundstjeneste timer vokser med 0,356 timer for hver dag, straffen øges - ud over en konstant på 53. De kortvarige straffe omregnes dermed til relativt mange samfundstjenestetimer.

Med virkning fra 1. juli 2000 blev området for samfundstjeneste udvidet til også at omfatte spirituskørsel og kørsel i frakendelsestiden. ${ }^{12}$ Samtidig blev mindstetiden sænket fra 40 til 30 timers samfundstjeneste, og sammenhængen mellem det antal timer, der idømmes, og længden af den straf, samfundstjeneste erstatter, er på dette område mere fastlagt. ${ }^{13}$ En dom til samfundstjeneste for spirituskørsel m.v. forventes endvidere at inkludere en bøde.

I de første 8 måneder, denne ordning har fungeret, er der idømt i alt $1888^{14}$ samfundstjenestedomme for spirituskørsel og kørsel i frakendelsestiden. Det forventes, at det årlige antal samfundstjenestedomme på færdselslovsområdet 
vil blive på omkring 2500. Antallet af domme på dette område overstiger således langt antallet af domme på straffelovs- og det øvrige særlovsområde.

Overholdelse af vilkårene for samfundstjeneste overvåges nøje. Overtrædelser kan i førstegangstilfælde føre til en advarsel fra Kriminalforsorgens side, mens alvorligere og/eller gentagne overtrædelser indberettes til domstolene. Ca. $10 \%$ af de dømte gennemfører ikke samfundstjenesten.

\section{b) Alkoholistbehandling for spiritusbilister}

Lov nr. 230 af 4. april 2000 om udvidet brug af samfundstjeneste omfatter også en lovændring vedrørende betingede domme med vilkår om alkoholistbehandling for spiritusbilister.

En sådan ordning har fungeret administrativt siden 1990, idet personer, der var idømt hæftestraf for spirituskørsel, og som havde behov for alkoholistbehandling, havde mulighed for at ansøge om i stedet at blive undergivet behandling for alkoholmisbrug. Desuden skulle de betale en bøde. Efter behandlingen, der varede et år, og betaling af en bøde blev personen benådet.

I en forsøgsperiode fra 1990-1994 omfattede ordningen straffe op til 40 dages hæfte, mens den, da den blev gjort permanent i 1994, kom til at omfatte hæftestraffe op til og med 60 dage.

Kriminalforsorgen administrerede denne ordning frem til lovændringen 1. juli 2000 , og det er stadig Kriminalforsorgen, der overvåger behandlingens gennemførelse. Med indførelse af muligheden for samfundstjeneste for spirituskørsel har det imidlertid været naturligt og nødvendigt at flytte kompetencen til at afgøre spørgsmålet om alkoholistbehandling til domstolene, således at domstolene samlet kan vurdere, om det drejer sig om en person, der pga. alkoholproblemer har behov for alkoholistbehandling, eller om det mest hensigtsmæssige alternativ til en frihedsstraf er samfundstjeneste.

Tallene for idømte behandlingsdomme i perioden 1. juli til 31. december 2000 tyder på en vis tilbageholdenhed med at idømme sanktionen lige efter lovændringen, med et gennemsnit på knap 40 domme pr. måned de første tre måneder. Derefter øger antallet af behandlingsdomme til knap 120 pr. måned de sidste 3 måneder. ${ }^{14}$ Fortsætter sidstnævnte tendens vil det årlige antal behandlingsdomme for spiritusbilister nå op på omkring 1500 pr. år, et tal der langt overskrider det antal behandlingsforløb, der blev påbegyndt under den administrative ordning. ${ }^{15}$ Den bekymring, der kunne være for, at samfundstjeneste ville overtage en del af det område, behandlingsordningerne tidligere dækkede, synes der dermed ikke at være grundlag for.

Med hensyn til manglende overholdelse af behandlingsforpligtelserne kan dette føre til forlængelse af behandlingsperioden eller til, at straffen ændres til en ubetinget dom. Opgørelser vedr. den administrative ordning har vist, at omkring $25 \%$ af dem i behandling overtrådte vilkårene. 


\section{c) Forsøgsordning med behandling af narkomaner}

På forsøgsbasis startede et behandlingsprogram som alternativ til frihedsstraf for narkomaner i 1995. Da forsøget startede, omfattede det Frederiksborg og Fyns Amt, men i september 1999 blev også Vejle Amt inkluderet i forsøget. Forsøget forventes afsluttet senest ved udgangen af 2002.

Forsøget omfatter kriminelle stofmisbrugere, der står til en ubetinget frihedsstraf på 6-12 mdr. Som alternativ til frihedsstraffen kan den tiltalte idømmes en betinget dom med vilkår om behandling for stofmisbrug. I den behandlingsmodel, der er valgt i Fyns Amt, varer behandlingen i et år, hvoraf 4 mdr. foregår i døgninstitution, mens den varer to år, med 6 mdr. i døgninstitution, i Frederiksborg Amt. Vejle Amt arbejder med et etårigt program, indeholdende ophold på døgninstitution i gennemgående 3-4 måneder.

Inden sagen kommer for en dommer, foretager den lokale Kriminalforsorg $\mathrm{i}$ Frihed en personundersøgelse med henblik på at vurdere den tiltaltes behandlingsbehov og egnethed. Den endelige afgørelse af, om den tiltalte er egnet til at indgå i forsøget, besluttes dog i fællesskab af et lokalt udvalg, bestående af det lokale behandlingscenter, den lokale socialforvaltning og Kriminalforsorg i Frihed.

Formelt skal den tiltalte ikke give sit samtykke til at indgå i behandlingen, men reelt vil spørgsmålet om motivation være af betydning for egnethedsvurderingen.

Det har vist sig vanskeligere at finde egnede deltagere til forsøget end antaget. I løbet af forsøgets første tre år har 63 personer deltaget i forsøget i Fyns Amt og 20 i Frederiksborg Amt. Årsagen til den store forskel i antal deltagere de to amter imellem er bl.a., at motivationen til at deltage i det etårige behandlingsprogram er større end motivationen til at deltage i det toårige.

I den forlængede forsøgsperiode synes tilgangen til forsøget dog at have accelereret noget, således at $\mathrm{i}$ alt 146 personer havde deltaget $\mathrm{i}$ forsøget frem til udgangen af maj 2000. ${ }^{17}$ Det skal bemærkes, at der er et begrænset antal pladser til rådighed for forsøget, maksimalt 25 pladser pr. år i Fyns Amt og 10 pladser i hver af de øvrige to amter.

Frafaldet har været stort: Af de i alt 146 optagne, var 88 faldet fra, 29 havde gennemført behandlingen og et tilsvarende antal var i gang med behandlingen ved udgangen af maj $2000 .^{18}$

Såfremt behandlingen afbrydes i utide, er udgangspunktet, at hele fængselsstraffen skal afsones. Dette udgangspunkt har været fulgt i praksis i langt den overvejende del af tilfældene. Da ordningen imidlertid har status som vilkår $\mathrm{i}$ forbindelse med en betinget dom, gælder de almene regler for betingede domme. Det betyder, at ved vilkårsbrud, som fx behandlingsophør, skal pågældende på ny stilles for en dommer, som - i stedet for at beslutte fuldbyrdelse af straffen - kan ændre vilkåret eller tildele en advarsel (straffelovens § 60). I nogle få tilfælde, hvor der kun var kort tid tilbage af den planlagte behandling, er fængselsstraffen ikke blev fuldbyrdet. 
Der er foretaget en evaluering af forsøgets første tre år. ${ }^{19}$ Heri konkluderes bl.a., at selv om gennemførelsesprocenten er ringe, ligger den over den, der er fundet $i$ en undersøgelse af døgnanbragte stofmisbrugere. Forsøget har desuden vist sig at modtage mange stofmisbrugere, som ikke tidligere har været $\mathrm{i}$ behandling, og som har haft en kummerlig tilværelse. Alle deltageres situation forbedres, når de går ind $\mathrm{i}$ behandlingsforløbet. Ingen er recidiveret til ny kriminalitet, så længe de har deltaget i behandlingen. Som sidegevinst har forsøget medført nye samarbejdsformer de involverede myndigheder imellem.

Det er planlagt, at forsøget igen skal evalueres, når det er afsluttet. Der sigtes på i den forbindelse at gennemføre en recidivundersøgelse, der også skal omfatte en kontrolgruppe, bestående af kriminelle stofmisbrugere fra amter, der ikke indgår i forsøget.

\section{d) Forsøgsordning med behandling af seksualforbrydere}

Forsøgsordningen, der startede i efteråret $1997,{ }^{20}$ omfatter to dele, hvoraf kun den ene er relevant i denne sammenhæng. Den ene del vedrører således ikke et alternativ til frihedsstraf, men består i en øget behandlingsindsats under afsoningen og i forbindelse med en prøveløsladelse.

Den anden del, der indebærer behandling som alternativ til frihedsstraf, omfatter seksualforbrydere, hvis forbrydelser ikke har omfattet vold eller tvang, og som forventes at blive idømt en ubetinget frihedsstraf på 4-6 mdr. og op til 1 år. Det indebærer, at behandlingsprogrammet primært sigter på personer, dømt for incest og blufærdighedskrænkelse. ${ }^{21}$ Personer, der findes egnede og motiverede til at indgå i dette forsøg, kan som alternativ til frihedsstraf blive idømt betinget dom med vilkår om psykiatrisk/sexologisk behandling i almindeligvis 2 år.

Inden en afgørelse om deltagelse i forsøgsordningen træffes, skal de tiltalte underkastes både en person- og mentalundersøgelse. På baggrund heraf indstiller et visitationsudvalg, bestående af en overlæge fra en af de deltagende behandlingsinstitutioner samt en repræsentant fra Kriminalforsorgen, om pågældende bør indgå $\mathrm{i}$ ordningen. Den endelig afgørelse træffes af en domstol.

Frem til april 2000 havde visitationsudvalget behandlet 114 sager, og i 86 tilfælde var personen fundet egnet til et deltage i forsøget. Heraf blev der i 56 sager idømt betinget dom med vilkår om behandling. I hvilket omfang, der i de resterende 30 sager er idømt anden sanktion, eller om der på opgørelsestidspunktet endnu ikke var afsagt dom, er uklart. ${ }^{22}$ På opgørelsestidspunktet var alene 5 personer færdigbehandlede, 50 var fortsat $\mathrm{i}$ behandling, mens behandlingen var afbrudt for én person.

Behandlingsdommene forventes almindeligvis at bestå af følgende tre dele: Et indledende ophold på en af Kriminalforsorgens pensioner i 4-6 mdr., ambulant behandling på en sexologisk klinik i omkring 1 år og tilsyn, evt. med vilkår om fortsat behandling, af Kriminalforsorgen i Frihed i ca. $6 \mathrm{mdr}$. 
Efter forsøgsperiodens ophør efteråret 2000 er ordningen med behandlingsdomme til seksualforbrydere gjort permanent. Evalueringen fortsætter dog, idet denne også skal omfatte en effektundersøgelse, der først vil være klar ved udgangen af 2002 .

\section{e) Ny ungdomssanktion}

Der er nok nogen, der vil sætte spørgsmålstegn ved, hvorvidt det forslag til ny ungdomssanktion, der for nylig er fremsat, og som forventes vedtaget inden sommeren 2001, skal betegnes som alternativ til frihedsstraf. Formelt tilhører det dog denne kategori.

Ønsket om en ny ungdomssanktion er begrundet i, at unge de seneste år har begået nogle alvorlige lovovertrædelser, herunder især gaderøverier og gruppevoldtægter. Det har rejst spørgsmålet, om de eksisterende sanktionsmuligheder er tilstrækkelige og effektive over for de hårdest belastede unge lovovertrædere. Derfor blev der i efteråret 2000 nedsat en Ekspertgruppe, der bl.a. skulle overveje nye sanktionsmuligheder over for unge kriminelle under 18 år. ${ }^{23}$

Dette har resulteret i forslag om, at unge lovovertrædere i aldersgruppen 1518 år, der har begået alvorlig kriminalitet, som alternativ til en ubetinget frihedsstraf på almindeligvis mellem 3 mdr. og 1 år kan undergives en struktureret, kontrolleret pædagogisk behandling af 2 års varighed. Behandlingen skal starte $i$ en sikret institution, derefter fortsætte på en almindelig institution eller andet, godkendt opholdssted, og der afsluttes med en udslusningfase og ambulant behandling. Opholdet i den sikrede institution forventes almindeligvis at vare 2 mdr. og kan højest vare 12 mdr. Den samlede opholdstid på institution (sikret og anden form) kan højest vare 1 år.

Det er domstolene, der træffer beslutning om denne ungdomssanktion.

Der har ikke været enighed i Ekspertgruppen om at foreslå denne særlige ungdomssanktion. Et mindretal, bestående af repræsentanter for amter og kommuner, ønsker ikke, at domstolene skal træffe beslutninger vedrørende behandlingsvarighed m.v. på det pædagogiske område, men at dette spørgsmål alene skal afgøres på baggrund af en socialpædagogisk vurdering. Desuden påpeges, at med forslaget sammenblandes straf og behandling, hvilket kan have uheldige følger. Tilsvarende er fremført fra socialpædagogisk hold og af andre, der arbejder med at behandle børn og unge. Især fremhæves, at det ikke er muligt at behandle inden for rammerne af de sikrede institutioner.

\section{Alternativ afsoning}

I forbindelse med afskaffelse af de strafferetlige særforanstaltninger i $1973 \mathrm{blev}$ der gennemført en udvidet mulighed for afsoning af frihedsstraf på andre institutioner end fængsler. ${ }^{24}$ Denne såkaldte alternative afsoning er omtalt i straffelovens $\S 49$, stk. 2, i straffeloven: "Findes det hensigtsmæssigt på grund af domfældtes alder, helbredstilstand eller andre særlige omstændigheder, kan justits- 
ministeren bestemme, at den pågældende midlertidigt eller for resten af straffetiden skal overføres til hospital eller til egnet hjem eller institution til særlig pleje eller forsorg."

I praksis er det Kriminalforsorgen, der træffer afgørelsen om alternativ afsoning, ligesom Kriminalforsorgen planlægger afsoningens indhold. Tilladelse til at afsone en straf på en alternativ institution gives primært til personer med et særligt behandlingsbehov samt til unge under 18 år. I forbindelse med Danmarks ratifikation af FNs Børnekonvention i 1991 ændredes praksis, således at muligheden for en $\S 49$, stk. 2-anbringelse overvejes for alle dømte under 18 år.

Bestemmelsen om alternativ afsoning blev dog ikke taget i anvendelse før i 1978, og i årene derefter og frem til 1988 var anvendelsen af alternativ afsoning ganske beskeden, med mindre end 50 alternative afsoningsforløb pr. år. Efter politiske tilkendegivelser i 1988 om en øget anvendelse af $\S 49$, stk. 2, over for bl.a. stofmisbrugere, steg antallet af sager imidlertid stærkt, og stigningen er fortsat i 1990'erne, således at bestemmelsen i slutningen af 1990'erne blev anvendt i mere end 300 tilfælde årligt. ${ }^{25}$

Alternativ afsoning gives med en række forskellige begrundelser: Alkoholeller narkotikamisbrug, psykiske eller fysiske helbredsproblemer, sociale årsager, ung alder m.v. Der er dog to grupper, der i dag dominerer området, nemlig stofmisbrugere og unge domfældte. $40-50 \%$ af de alternative afsoningsforløb angår førstnævnte gruppe, mens omkring en fjerdedel vedrører sidstnævnte. Tidligere angik forholdsvis mange alternative afsoninger personer med alkoholproblemer, men denne gruppe er blevet mindre gennem 1990'erne. ${ }^{26}$

Under den alternative afsoning er personerne i tilsyn af Kriminalforsorgen $\mathrm{i}$ Frihed, som også kontrollerer overholdelse af forpligtelser m.v. I 1999 gennemførte $86 \%$ det alternative afsoningsforløb, mens de øvrige 14\% fik forløbet afbrudt pga. vilkårsovertrædelser o.lign. Gennem 1990'erne har andelen, der gennemfører forløbet, været voksende, på trods af at stadig flere afsoner alternativt. ${ }^{27}$

I en omfattende evaluering konkluderes bl.a., at alternative afsoningsforløb har en specialpræventiv effekt, idet kriminalitetens alvorlighed og omfang aftager i forbindelse med en alternativ afsoning. ${ }^{28}$ Undersøgelsens konklusion er dog ikke baseret på sammenligning med en kontrolgruppe, hvorfor den må betragtes som usikker.

\section{Nyere samfundssanktioner}

Af nyere samfundssanktioner kan der for Danmarks vedkommende alene peges på den særlige ordning med ungdomskontrakter. Denne startede i 1990 som en forsøgsordning og blev i 1998 gjort permanent.

Udgangspunktet for gennemførelse af denne ordning var kritik af tiltalefrafald, som man fra politisk hold mente var for lemfældig i sit pønale indhold og derfor ikke tilstrækkelig effektiv. ${ }^{29}$ Man ønskede at indføre en ordning, der af 
den unge opfattes som mere konsekvent og mærkbar. Et væsentligt ønske med den nye ordning var også, at ungdomskontrakten, med henblik på at opnå en pædagogisk effekt, skulle indgås meget hurtigt.

Ordningen vedrører unge, der modtager et tiltalefrafald efter retsplejelovens $\S$ 722 , stk. 1 , nr. 2 og nr. 3. Som noget nyt blev det med denne ordning muligt at give et vilkår om ungdomskontrakt.

Anvendelsesområdet for ungdomskontrakter er sager vedrørende berigelseskriminalitet og brugstyverier. ${ }^{30}$ Ungdomskontrakt skal ifølge Rigsadvokaten "især tilbydes 15-17-årige, der ikke er kommet ind i et mere fast kriminalitetsmønster. Det er unge, som efter hidtil gældende retspraksis skulle have tiltalefrafald med vilkår om tilsyn af de sociale myndigheder m.v. eller eventuelt den første betingede dom". Videre nævnes, at det typisk vil dreje sig om unge, "der har begået indbrudstyveri eller andet tyveri, visse hærværksforhold eller brugstyveri af cykler eller knallerter eller helt enkeltstående brugstyverier af biler uden samtidig forvoldelse af konkret fare for skade på personer eller ting". ${ }^{31}$

Udkast til ungdomskontrakten udarbejdes af de sociale myndigheder i fællesskab med den unge og dennes forældre. Kontrakten skal derefter godkendes at politiet, hvorefter den underskrives af alle de nævnte parter. Ungdomskontrakten vil typisk forpligte den unge til i en periode at deltage i visse aktiviteter, jf. nedenstående.

En undersøgelse af de ungdomskontakter, der blev indgået i perioden 1. januar 1999 til 30. juni $1999,,^{32}$ viser, at et stort flertal af kontrakterne indeholder aftaler vedrørende den unges skolegang og/eller erhvervsuddannelse, og at næsten halvdelen af kontrakterne omhandler den unges fritid. Desuden omfatter de fleste ungdomskontrakter aftaler om en personlig rådgiver eller en fast kontaktperson. I gennemsnit er der knyttet aftaler om tre forskellige forhold til de enkelte ungdomskontrakter.

Med hensyn til ambitionen om hurtigt at iværksætte tiltalefrafald med vilkår om ungdomskontrakt synes denne ikke helt at blive indfriet, idet ovennævnte undersøgelse viser, at der i gennemsnit går $6 \mathrm{mdr}$. fra gerningstidspunktet, til tiltalefrafaldet med vilkår om ungdomskontrakt er godkendt.

Under forsøgsordningen med ungdomskontrakt blev sanktionen ikke påført den unges straffeattest, såfremt aftalerne blev overholdt. Dette element indgår dog ikke i den permanente ordning, idet det blev anset for urimeligt i forhold til de unge, der har begået mindre alvorlige lovovertrædelser, og som derfor får en bøde - der tilføres straffeattesten. Med permanentgørelse af ordningen er der til gengæld sket en reduktion i den tid, tiltalefrafald med vilkår og bøder figurerer på straffeattesten, idet den første bøde og det første tiltalefrafald med vilkår om ungdomskontrakt, der gives til unge under 18 år, kun vil optræde på en privat straffeattest $i 1$ år, mod tidligere 2 år.

I 1999 blev der indgået 163 ungdomskontrakter og i 2000 180. Det svarer til noget knap halvdelen af alle de tiltalefrafald, der gives til unge lovovertrædere. 


\section{Andre nydannelser}

Som i de øvrige nordiske lande er der også i Danmark arbejdet med konfliktråd. Den danske ordning med konfliktråd kan dog ikke siges at henhøre under begrebet samfundssanktioner, idet konfliktråd ikke erstatter, men alene supplerer den almindelige restforfølgning. Der er dog mulighed for, at spørgsmålet om konfliktrådsbehandling kan medinddrages i strafudmålingen og påvirke denne. Dette er sket i en voldssag, hvor dommen er gjort betinget under henvisning til konfliktrådsbehandlingen.

Det første danske forsøg med konfliktråd blev igangsat i forlængelse af regeringens første voldspakke fra 1994. Dette forsøg, der primært fokuserede på unge voldsmænd, viste sig at være alt for snævert, så kun ganske få sager blev behandlet i konfliktråd. Forslag til et nyt forsøg med konfliktråd blev derfor fremsat sammen med regeringens handleplan for styrkelse af ofres retsstilling $i$ 1997. Forsøget, der omfatter 3 politikredse, startede i 1998 og planlægges afsluttet i 2002.

Betingelsen for, at en sag kan behandles i konfliktråd, er, at det er en tilståelsessag, og at såvel offer som gerningsperson giver samtykke til at deltage. Frem til foråret 2001 er der i alt behandlet 88 sager i konfliktråd. Andre 127 sager er af forskellige grunde ikke er endt med konfliktrådsbehandling.

Eftersom den danske konfliktrådsmodel ikke fungerer som en alternativ sanktion, kunne man forvente, at der ville være ganske mange gerningsmænd, der ikke ønskede konfliktrådsbehandling, da det ikke nødvendigvis vil stille deres sag bedre. Af en midtvejsevaluering fremgår det imidlertid, at andelen af ofre, der ikke har ønsket at deltage i konfliktråd, er større. ${ }^{33}$ Andelen af gerningspersoner, der ikke har ønsket at deltage, er således $41 \% \bmod 59 \%$ af ofrene.

Den nævnte midtvejsevaluering viser i øvrigt, at de, der har deltaget i konfliktråd, i 9 ud af 10 tilfælde synes, det har været vellykket, og de fleste har haft stort udbytte af det.

\section{Afsluttende bemærkninger}

Hvilken betydning har samfundssanktionerne? Har de medført radikale ændringer i sanktionssystemet?

Ud fra et overordnet, statistisk perspektiv, som illustreret i figur 3, må svaret på sidstnævnte spørgsmål være nej. Nydannelserne er knapt synlige, hvilket ikke skyldes, at de forskellige former for behandlingsalternativer til frihedsstraf ikke er opgjort særskilt. Tallene herfor er således ganske små. 
Figur 3. Afgørelser for straffelovsovertrcedelser 1974-2000, kumuleret. ${ }^{34}$

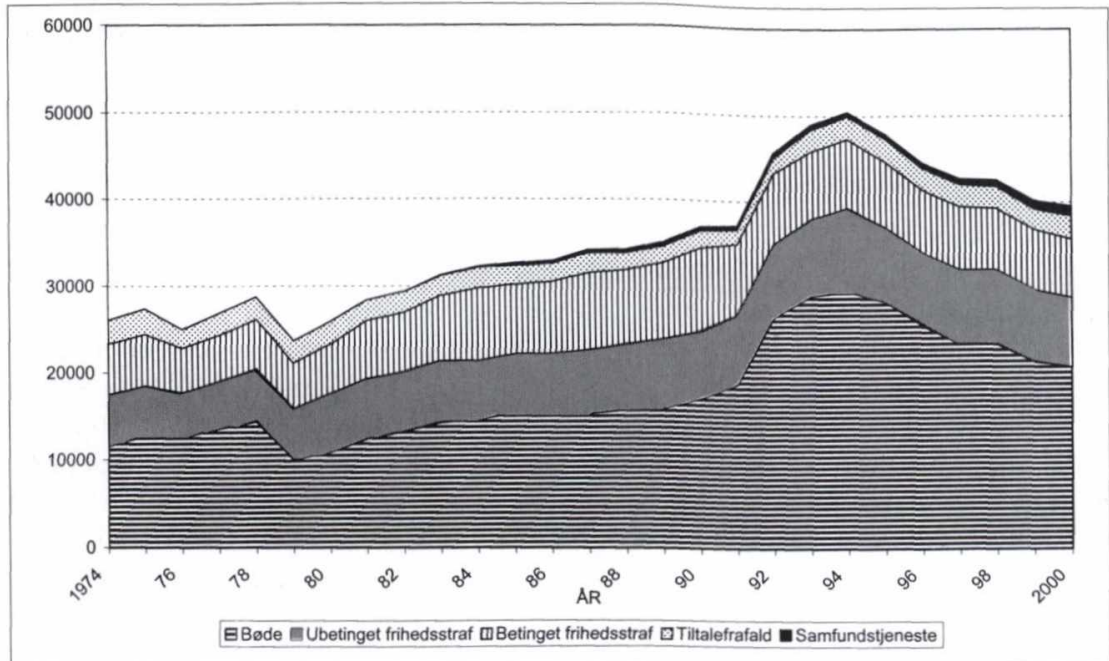

Betydningen af de forskellige ordninger, der søger at reducere brugen af ubetingede fængselsstraffe, kan imidlertid også anskues ud fra, i hvilket omfang dette er lykkedes. Som det ses af figur 4, har fangetallet ligget ret så konstant i de seneste 2-3 decennier, og selv før da - helt tilbage til begyndelsen af 1950'erne - har vi haft et ganske stabilt fangetal i Danmark. ${ }^{35}$ Det kan således næppe påstås, at fangetallet - som følge af de seneste par decenniers reformer på samfundssanktionsområdet - er mindsket.

Figur 4. Udviklingen $i$ anmeldte straffelovsovertradelser og $i$ det gennemsnitlige daglige beloeg i fangslerne, 1974-2000, indeks.

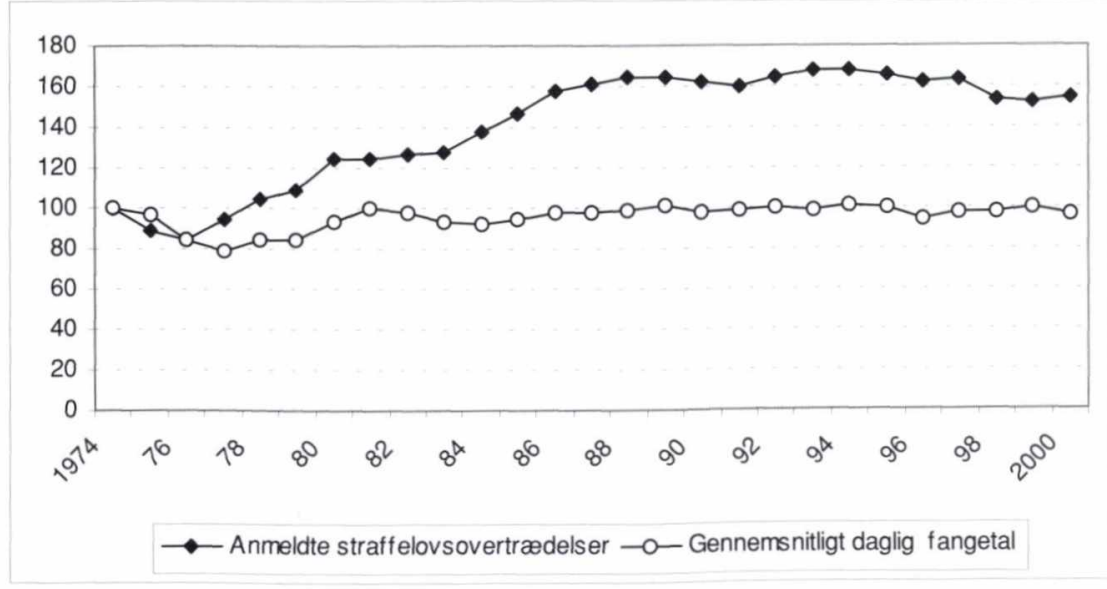


Figur 4 viser imidlertid også, at mens fangetallet har været uforanderligt, er antallet af anmeldte straffelovsovertrædelser vokset med $60 \%$ fra midten af 70'erne til slutningen af 80'erne. Siden da har dette tal også været stabilt, endda med faldende tendens de seneste år. Set i denne sammenhæng kan det med en vis ret hævdes, at de forskellige former for samfundssanktioner i hvert fald har medvirket til at holde fangebefolkningen på et ganske konstant niveau på trods af vækst i antallet af forbrydelser. De, der har kendskab til øvrige reformer på det strafferetlige område, vil vide, at andre forhold, såsom nedkriminaliseringer og sænkning af strafudmålingsniveauet på især berigelsesområdet - har haft en større betydning for det stabile fangetal.

Figur 3 og tildels også figur 4 vedrører alene straffelovsområdet. På et andet område - nemlig færdselslovsområdet - er der ikke tvivl om, at samfundssanktionerne, især med den nævnte lovændring i 2000, har en markant betydning.

På straffelovsområdet er de nye samfundssanktioner imidlertid indtil videre af større ideologisk og symbolsk betydning end af praktisk betydning. Såfremt den udvikling, der har fundet sted det seneste tiår, fortsætter i samme takt, kan der dog være grund til at antage, at samfundssanktioner vil indtage en mere markant rolle i det danske sanktionssystem $\mathrm{i}$ en ikke alt for fjern fremtid.

Noter:

' Se Sten Heckscher, Annika Snare, Hannu Takala and Jørn Vestergaard (red.). 1980. Straff och rättfärdighet - ny nordisk debatt. Stockholm: Norstedts.

${ }^{2}$ Betænkning nr. 806, 1997, s. 7.

${ }^{3}$ Ibid., s. 7.

${ }^{4}$ Ibid., s. 9.

${ }^{5}$ Straffelovrådets betænkning om samfundstjeneste. Betænkning nr. 1211, København 1990

${ }^{6}$ Britta Kyvsgaard: Samfundstjeneste i empirisk belysning. Juristen, $n r .4,1999$.

${ }^{7}$ Lov nr. 274 af 15. april 1997

${ }^{8}$ Jørgen Goul Andersen: Borgerne og lovene. Aarhus Universitetsforlag, 1998.

${ }^{9}$ Kriminalforsorgens Statistik 1999, s. 62.

${ }^{10}$ Se Straffelovrådets betænkning om samfundstjeneste, op.cit.

"Fra Britta Kyvsgaard, 1999, op.cit.

${ }^{12}$ Lov nr. 230 af 4 . april 2000.

${ }^{13}$ Vagn Greve: Straffuldbyrdelsesloven - og andre væsentlige ændringer i det danske sanktionssystem. NTfK, årg. 88, s. 16.

${ }^{14}$ Tallet inkluderer også hæftestraffe, der i forbindelse med en overgangsordning blev ændret administrativt til samfundstjeneste.

${ }^{15}$ Mundtlige oplysninger fra Kriminalforsorgen.

${ }^{16}$ Frem til lovændringen i 2000 var det omkring 1000 personer årligt, der kom i alkoholistbehandling i forbindelse med en dom for spirituskørsel.

${ }^{17}$ Rapport om forsøgsordning med behandling af kriminelle stofmisbrugere som alternativ til ubetinget frihedsstraf. Socialministeriet - Justitsministeriet, oktober 2000.

${ }^{18}$ Diverse notater fra Anette Storgaard.

${ }^{19}$ Anette Storgaard: Behandling $i$ stedet for faengselsstraf til nogle kriminelle stofmisbrugere. Center for Rusmiddelforskning, Arhus Universitet, 1999.

${ }^{20}$ Lov nr. 274 af 15 . april 1997. 
${ }^{21}$ Se dog Beth Grothe Nielsen: Forsøgsordningen med behandling af seksulaforbrydere. Ugeskrift for Retsveesen 2001 s. 155-159, der omtaler en sag, hvor en person, dømt for voldtægt, er omfattet af forsøget.

${ }^{22}$ Se Evalueringsrapport om forsøgsordningen vedrørende en forstarket behandlingsindsats over for personer, der er dømt for seksualforbrydelser. www.kriminalforsorgen.dk.

${ }^{23}$ Rapport om ungdomskriminalitet. Afgivet af Ekspertgruppen om ungdomskriminalitet, Justitsministeriet januar 2001. Også tilgængelig på ministeriets hjemmeside: www.jm.dk.

${ }^{24}$ Desuden fik Kriminalforsorgen hjemmel til at give indsatte ophold uden for fængslet med henblik på deltagelse i undervisning eller til beskæftigelse, den såkaldte frigangsordning. Se lov nr. 319 og lov nr. 320, begge af 13. april 1973.

${ }^{25}$ Lisbeth Hansen og Peter Løvgreen: Udviklingen i brug af alternativ afsoning. København: CASA, 1999. Helle Hagemann og Claus B. Olsen: Alternativ afsoning efter straffelovens $\S 49$, stk. 2. København: CASA 2001.

${ }^{26}$ Ibid.

${ }^{27}$ Ibid.

${ }^{28}$ Ibid., samt Lisbeth Hansen og Peter Løvgreen: Paragraf 49, stk2-afsoneres kriminelle karriereforløb. København: CASA, 2000.

${ }^{29}$ Juvenile Contracting in Denmark: Paternalism Revisited. Scandinavian Studies in Criminology, vol. 12, pp. $72-97$

${ }^{30}$ Rigsadvokatens Meddelelse nr. 7/1998 om behandlingen af sager mod unge lovovertrædere.

${ }^{31}$ Ibid.

${ }^{32}$ Rigsadvokaten Informerer $n$ r. 2/2000.

${ }^{33}$ Claus Syberg Henriksen: Midtvejsevaluering af Konfliktråd i Danmark. København: CASA, 2000.

${ }^{34}$ Tal for 2000 er foreløbige.

${ }^{35}$ Undtagelsen er slutningen af 1970 'erne, hvor fangetallet - sammen med et fald i den anmeldte kriminalitet - mindskede.

Adresse: Justitsministeriet

Slotsholmsgade 10

DK - 1216 København K.

e-post: bky@jm.dk 